\title{
Role of the Security Council in triggering the jurisdiction of the international criminal court
}

\section{Introductory}

The International Criminal Court (hereinafter ICC) came in to force in 2002. The main idea of ICC was to remove the impunity. It aims to the bring perpetrators of international crimes to justice. ${ }^{1}$ The Preamble of the ICC states that these crimes threaten the peace, security, and well-being of the world and must not go unpunished. ${ }^{2}$ The International Criminal Court can normally exercise its jurisdiction over the States which became a party to the Rome Statute. ${ }^{3}$ The International Criminal Court has four distinct organs: the three Trial Divisions, the Presidency, the Office of the Prosecutor, and the Registry. The ICC divides its eighteen judges among three Trial Divisions: the Pre-Trial Chambers, the Trial Chambers, and the Appeals Chamber. ${ }^{4}$ Each Pre-Trial Chamber admits evidence, issues warrants, and determines if a crime falls under the ICC's jurisdiction. ${ }^{5}$ The two Trial Chambers conduct trials and sentence the convicted. ${ }^{6}$ The Appeals Chamber hears appeals and has the power to reverse or amend a decision or sentence or arrange for a new trial before a different Trial Chamber. ${ }^{7}$ One of the eighteen judges serves as the President and two serve as Vice-Presidents. ${ }^{8}$ These individuals are responsible for administrative matters, such as assigning cases to the Pre-Trial Chambers. ${ }^{9}$ The ICC has subject matter jurisdiction over genocide, crimes against humanity, war crimes, and crimes of aggression. ${ }^{10}$ The trigger mechanisms for jurisdiction are

1. Referral to the prosecutor by a party to the Rome Statute,

2. Referral by the Security Council acting under Chapter VII of the UN Charter, and

3. Referral by the Prosecutor himself in accordance with Article 15 of the Rome Statute. ${ }^{11}$ The ICC is not an organ of the UN.

${ }^{1}$ At the end of World War I, momentum for a permanent international criminal court slowly began to build. The Treaty of Versailles called for the establishment of an international criminal tribunal to try the German Emperor, Kaiser Wilhelm, for "a supreme offense against morality and the sanctity of treaties," but he never actually stood trial. More importantly, a treaty providing for an international criminal tribunal to try Turkish leaders accused of slaughtering millions of Armenians was never ratified, and the alleged perpetrators were granted amnesty.

${ }^{2}$ Joshua B. Bevitz, "Flawed Foreign Policy: Hypocritical U.S. Attitudes Towards International Criminal Forums," Hastings Law Journal, Vol. 53, April, 2002, pp. 931-962, at p. 940.

${ }^{3}$ Yusuf Aksar, "The UN Security Council and the Enforcement of Individual Criminal Responsibility: The Dafur," African Journal of International and Comparative Law, Vol. 14, No. 1, 2006, pp. 104-119, at p. 118.

${ }^{4}$ Article 36 of the Rome Statute

${ }^{5}$ Article 57 of the Rome Statute

${ }^{6}$ Article 76 of the Rome Statute

${ }^{7}$ Article 83 (2) of the Rome Statute

${ }^{8}$ Article 38 of the Rome Statute

${ }^{9}$ Elizabeth C. Minogue, "Increasing the Effectiveness of the Security Council's Chapter VII Authority in the Current Situations Before the International Criminal Court," Vanderbilt Law Review, Vol. 61, March 2008, pp. 647-680, at p. 653.

${ }^{10}$ Article 5 of the Rome Statute.

${ }^{11} \mathrm{http}: / / \mathrm{www} 2 . \mathrm{icc}-\mathrm{cpi}$.int/Menus/ICC/Situations+and+Cases/ Referals+and+communications, visited on 10 September, 2010
Volume 4 Issue 5 - 2017

Sangeeta Taak

Rajiv Gandhi National University of Law, India

Correspondence: Sangeeta Taak, Rajiv Gandhi National University of Law, Sidhuwal Bhadson Road, Patiala, India,Tel 9872777330,Email sangeetataak8I@gmail.com

Received: December 17, 2016 | Published: May 03, 2017

\section{Historical background}

The ad hoc tribunal created in Nuremberg after World War II set a precedent for the international community to hold individuals responsible for grave crimes, even though state responsibility still maintained a role at Nuremberg. ${ }^{12}$ The ad hoc criminal Tribunals established to address the crises in the former Yugoslavia and in Rwanda continued the pattern of holding individuals responsible for serious breaches of human rights law such as genocide, crimes against humanity, and war crimes. ${ }^{13}$ The international community recognized, however, the need for a permanent court for the trial of these transgressions, rather than the continual establishment of ad hoc tribunals in response to each period of serious human rights violations. ${ }^{14}$

In response to this demonstrated need, the international community agreed on the idea of the ICC. The ICC was to be the first court established in advance of, rather than in response to, international human rights violations. ${ }^{15}$ In constructing the definitions of crimes that

\footnotetext{
${ }^{12}$ Nuremberg dictum stating "crimes against international law are committed by men, not byabstract entities" has been used to affirm individual criminal responsibility for international crimes. (citing The Trial of German Major War Criminals Sitting at Nuremberg, Judgment, 1946, 41-42.

${ }^{13}$ Statute of the International Tribunal for the Prosecution of Persons Responsible for Serious Violations of International Humanitarian Law Committed in the Territory of the Former Yugoslavia since 1991, S.C. Res. 827, arts. 1-5, U.N. Doc. S/RES/827 (May 25, 1993) [hereinafter ICTY Statute]. Article 1 states, "The International Tribunal shall have the power to prosecute persons responsible for serious violations of international humanitarian law committed in the territory of the former Yugoslavia since 1991 in accordance with the provisions of the present Statute." Id. art. 1 (emphasis added). Articles 2-5 contain definitions for crimes within the jurisdiction, such as genocide, crimes against humanity, and war crimes. Id. arts. 2-5; see also Statute of the International Criminal Tribunal for the Prosecution of Persons Responsible for Genocide and Other Serious Violations of Humanitarian Law Committed in the Territory of Rwanda and Rwandan Citizens Responsible for Genocide and Other Such Violations Committed in the Territory of Neighboring States, Between 1 Jan. 1994 and 31 Dec. 1994, U.N. Doc. S/RES/955 (Nov. 8, 1994) [hereinafter ICTR Statute]. Article 1 states:

${ }^{14}$ The International Tribunal for Rwanda shall have the power to prosecute persons responsible for serious violations of international humanitarian law committed in the territory of Rwanda and Rwandan citizens responsible for such violations committed in the territory of neighbouring States, between 1 January 1994 and 31 December 1994, in accordance with the provisions of the present Statute.
}

${ }^{15}$ Previous ad hoc "tribunals at Nuremberg and Tokyo, may be called ex post 
would fall within the Court's jurisdiction, the international community relied upon the statutes for the two regional criminal courts: the International Criminal Tribunal for the former Yugoslavia (ICTY) and International Criminal Tribunal for Rwanda (ICTR). ${ }^{16}$ In July of 1998, the Rome Statute was adopted at the U.N. Diplomatic Conference of Plenipotentiaries on the Establishment of an International Criminal Court, also known as the Rome Conference. ${ }^{17}$ On July 1, 2002, the Rome Statute entered into force after ratification by sixty State Parties. ${ }^{18}$

\section{Triggering mechanism}

Three trigger mechanisms ways in which the ICC assumes jurisdiction over the specified crimes are provided for under the Statute.

1. Referral by a State Party (including self-referral, as in the case of Uganda, the Central African Republic and the DRC)

2. Referral by the Security Council in exercise of its powers under Chapter VII of the UN Charter (for example, Darfur, Sudan)

3. Investigation initiated by the Prosecutor of the ICC of his own accord.

The fourth possibility is where a state that is not a party to the Rome Statute makes a declaration allowing the Court jurisdiction over acts committed on its territory. ${ }^{19}$ The recent release of the ICC Prosecutor's Report on his investigations of the Darfur situation indicates that little progress has been made towards the Court's first prosecutions..$^{20}$ Although evidence has been collected and catalogued and a staff has been hired, it is unclear when the first prosecutions will

tribunals, in that they are established after the acute and violent situation in which the alleged crimes occurred....[E]x ante tribunals...are established before an international security problem has been resolved or even manifested itself....The ICC is the archetypal ex ante tribunal." Arsanjani and Reisman

${ }^{16}$ For example, Article 6 of the Rome Statute, defining genocide, contains text identical to that of Article 4(2) of the ICTY Statute. Compare Rome Statute, supra note 1, art. 6 ("Genocide' means any of the following acts committed with intent to destroy, in whole or in part, a national, ethnical, racial, or religious group, as such [listing relevant acts][.]") with ICTY Statute, supra note 11, art. 4 ("Genocide means any of the following acts committed with intent to destroy, in whole or in part, a national, racial, ethnical, or religious group, as such [listing relevant acts identical to ones listed in Article 6 of the Rome Statute."). Also, the text of Article 7 of the Rome Statute, defining crimes against humanity, parallels the text of Article 5 of the ICTY Statute defining the same crime, with the exception of further defined sex crimes in Section 1 (g) of Article 7 of the Rome Statute and the inclusion of the crime of apartheid in Section 1(j) of Article 7 of the Rome Statute. Compare Rome Statute, supra note 1 , art. 7, with ICTY Statute, supra note 11, art. 5. Furthermore, Article 8 of the Rome Statute incorporates grave breaches of the Geneva Conventions of 1949 into its definition of war crimes. Rome Statute, supra note 1, art. 8. Similarly, the ICTR and ICTY Statutes also criminalize grave breaches of the Geneva Conventions. ICTR Statute, supra note 11, art. 4 ("Violations of Article 3 Common to the Geneva Conventions and of Additional Protocol II"

${ }^{17}$ The Rome Statute is an international treaty. However, because it is a treaty that establishes an institution, it is referred to as a statute.

${ }^{18}$ Christopher D. Totten and Nicholas Tyler, "Arguing for an Integrated Approach to Resolving the Crisis in Darfur: The Challenges of Complementary, Enforcement, and Related Issues in the International Criminal Court," Journal of Criminal Law and Criminology, Vol. 98, Spring, 2008, pp. 1069-1118, at p. 1079.

${ }^{19}$ George P. Fletcher, “The ICC- Two Courts in One?", Journal of International Criminal Justice, Vol. 4, July, 2006, pp. 428- 433, at p. 428.

${ }^{20}$ Second Report of the Prosecutor of the International Criminal Court, Mr Luis Morenv Ocampo, to the Security Council Pursuant to UNSCR 1593 (2005), $1^{3}$ December 2005 begin, much less be completed. Furthermore, there is no indication yet of whether the Court is sufficiently developed to handle the complexity of the Darfur situation investigated by the Special Commission and ultimately referred to it by the Security Council. ${ }^{21}$

\section{Role of the security council under the ICC}

On 26 May 2004, in a presidential statement, the Security Council expressed 'its grave concern over the deteriorating humanitarian and human rights situation in the Darfur region..$^{22}$ It reported to the Secretary-General on 25 January 2005. On 31 March 2005 the Security Council made its first referral to the International Criminal Council ('the ICC'). The Council referred the situation in Darfur to the Prosecutor of the ICC. Given the USA's stated opposition to the ICC, that there was a referral at all could be seen as a triumph for the Court's supporters. The International Commission of Inquiry on Darfur began its work on 25 October 2005. However, Security Council Resolution 1593 has a number of problematic features. Its genesis was long and convoluted, and it has been seen by some as a substitute for effective action by the United Nations to end the humanitarian crisis and systematic atrocities being committed in Darfur. ${ }^{23}$ The Commission concluded that the Government of Sudan and the janjaweed were responsible for serious violations of international human rights and humanitarian law. Government forces and militias had killed civilians; engaged in torture, forced disappearances, sexual violence and forced displacement; destroyed villages, and pillaged. Such acts amounted to war crimes and (given that they had been committed on a widespread and systematic basis) crimes against humanity. ${ }^{24}$ The Commission, however, concluded that the government of Sudan had not pursued a policy of genocide, although it considered that some individuals might have acted with genocidal intent. Acting under Chapter VII of the United Nations Charter, the Council decided to 'refer the situation in Darfur since 1 July 2002 to the Prosecutor of the International Criminal Court' and ordered the Government of Sudan and all other parties to the conflict in Darfur to 'cooperate fully with and provide any necessary assistance to the Court and the Prosecutor' pursuant to the resolution.

All this was in accordance with the power given to the Security Council under Article 13 of the Rome Statute of the International Criminal Court to trigger the Court's jurisdiction by acting under Chapter VII of the UN Charter to refer 'a situation in which one or more crimes appear to have been committed' to the Prosecutor.

\footnotetext{
${ }^{21} \mathrm{Id}$

${ }^{22}$ Statement of the President of the Security Council (26 May 2004) UN Doc S/ PRST/2004/18a1. The statement followed a report of the UN High Commission for Human Rights 'Situation of human rights in the Darfur region of the Sudan', UN Doc. E/CN.4/2005/3, 7 May 2004, in which the High Commissioner reported that massive and gross human rights violations were being committed in Darfur, possibly amounting to war crimes and crimes against humanity.

${ }^{23}$ Mathew Happold, "Darfur, The Security Council, and the International Criminal Court," International and Comparative Law Quarterly, Vol. 55, No. 1, 2006, pp. 226-36, at p. 226.

24 A treaty appears to be the most appropriate procedure to establish a permanent international criminal court, although the Security Council may be competent to establish such a court itself. However, this would require that the competence of the court be limited to specific situations, since a Security Council decision would be taken ex post and not ex ante. As an enforcement measure under Chapter VII, the Tribunals will therefore be terminated upon the determination by the Security Council that international peace and security has been restored in the former Yugoslavia and in Rwanda. For further see, Catherine Cisse, "The International Tribunals for the Former Yougoslavia and Rwanda: Some Elements of Comparison,” Transnational Law Contemporary Problems, Vol. 7, Spring, 1997, pp. 103-120, at p. 110.
} 
However, the Resolution also contained some rather more problematic provisions as a result of the compromises necessary to ensure its adoption. ${ }^{25}$ The Darfur Resolution places states that are both members of the UN and members of the ICC in a difficult position. Article 25 of the UN Charter requires member states to "accept and carry out" decisions of the Security Council that are "in accordance" with the UN Charter. ${ }^{26}$ However, if the peacekeeping exemption is determined to be counter to the powers granted to the Security Council, and thus not in accordance with the UN Charter, then UN member states would not be bound by it. ${ }^{27}$ On the other hand, if the peacekeeping exemption is deemed to be within the powers of the Security, then Article 103 of the UN Charter obligates UN member states to fulfil their obligations under the Charter over any obligations present in contradictory international instruments, which would include the Rome Statute. ${ }^{28}$

\section{Security council power under art. 16 of the rome statute}

Art. 16 requires the Court to defer any investigation or prosecution for a period of up to 12 months after the Security Council, in a resolution adopted under Chapter VII of the Charter, has requested the Court to that effect. ${ }^{29}$ The Article is intended to give the Security Council the possibility to suspend investigations or prosecutions by the Court, with respect to a certain case or a situation, when the Court's action threatens to disrupt the efforts of the Security Council to achieve peace. In particular, this danger is said to be present when the participation of a suspect in peace negotiations appears necessary or the prospect of prosecution may hold the parties to a conflict from reaching a peaceful solution. Art. 16 allow the Security Council, at least for a limited period of time, to lend international validity to a national amnesty or to prevent prosecution by the Court even without an amnesty having been granted at the national level..$^{30}$ Initially, this provision had been expected not to have great practical impact, as, under Art. 27 of the Charter, are quest to the Court requires the consensus of at least nine members of the Council, including the five permanent members, two of which are also States Parties to the Statute. However, Resolutions 1422 (2002) and $1487(2003)^{31}$ on the exemption of non State Party personnel of UN established or authorized operations from the Court's jurisdiction even though not renewed in 2004 as well as Resolution $1497(2003)^{32}$ on the conflict in Liberia have made clear that the Security Council can and will be used to try to limit the Court's range of action. ${ }^{33}$ The Security Council unanimously approved both Resolutions 1373 and 1540, reflecting approbation of counter proliferation and counterterrorism

${ }^{25}$ Resolution 1593 was adopted by 11 votes to none, with four abstentions (Algeria, Brazil, China, and the USA).

${ }^{26}$ U.N. Charter art. 25.

${ }^{27}$ Heather Cash, "Security Council Resolution 1593 and Conflicting Principles of International Law: How the Future of the International Criminal Court is at Stake," Brandeis Law Journal, Vol. 45, Spring 2007, pp. 573-599, at p. 589.

${ }^{28}$ Ibid

${ }^{29}$ Helmut Gropengieber, "Amnesties and the Rome Statute of the International Criminal Court," International Criminal Law Review, Vol. 5, 2005, pp. $267-$ 300 , at p. 270

${ }^{30}$ Id at p. 272

${ }^{31}$ Security Council Resolutions 1422 (2002), 1487 (2003) and 1497 (2003), excluding the jurisdiction of the ICC, give rise to the fundamental issue of whether the legitimacy of an international institution such as the International Criminal Court may be eroded by an act of the Security Council, the political organ of the United Nations.

${ }^{32}$ Resolutions 1422, 1487, 1497 and the International Criminal Court: Annulments of the Treaty Process.

${ }^{33}$ Ibid goals. Resolutions 1422, 1487, and 1497, however, are instances where the Council ${ }^{34}$ used its new legislative authority for unabashedly partisan purposes--to narrow the jurisdiction of the International Criminal court, as set forth in the Rome Treaty, for the benefit of states that opposed that tribunal. The history of these resolutions proves that Council legislative authority can be abused to actively annul the will of the international community as expressed in treaties. ${ }^{35}$

\section{Discretionary powers of the security council}

It is widely accepted that the maintenance of international peace and security is the principal objective of the $\mathrm{UN}$, and that this objective assumes precedence over all other commitments of the Organization. According to the scheme of the UN Charter, the Security Council is the primary organ entrusted with the responsibility of fulfilling this objective. ${ }^{36}$ The Council is thus required to act in situations that necessitate swift and urgent action on its part. It is therefore only natural that the Security Council should enjoy broad powers in the discharge of its functions with a view to maintaining international peace. The drafting history of the UN Charter indicates that unsuccessful attempts were made during the San Francisco Conference to qualify the words 'maintenance of international peace and security' in Article 1, with the words 'in conformity with the principles of justice and international law'. Such attempts failed due to apprehensions that such qualification would unduly limit the powers of the Council and prejudice effective action on its part. The wide measure of discretion thus accorded to the Council is particularly true of enforcement measures taken by the Council acting under Chapter VII. Under Article 39, the Council's powers to decide which situations constitute a threat to international peace and security, as well as what kind of responsive measures should be taken to quell a threat, are almost plenary. ${ }^{37}$ It would scarcely be compatible with the functions of the Council to allege otherwise. ${ }^{38}$ Decisions of the Security Council while acting under Chapter VII are essentially political decisions and unless the Council can exercise a wide measure of discretion, its functioning would be paralysed. The Security Council has therefore in the past exercised a wide array of powers while acting under Chapter VII including the establishment of international tribunals with primary jurisdiction over national courts and the settlement of border disputes between nations. ${ }^{39}$

Nevertheless, while the Security Council may enjoy an extensive range of powers under the UN Charter, it cannot act legibus solutus (unbound by law). While any decision of the Security Council while acting under Chapter VII must necessarily be a political decision that does not automatically imply that the Council can act without any deference to the principles of international law. The Security Council is a creature of treaty, and may not overstep the bounds of that treaty. Further, the Security Council is a delegate of the discretionary powers

${ }^{34}$ Also See, Inger Osterdahl, "Max Hilaire: United Nations Law and the Security Council," European Journal of International Law, Vol. 17, November, 2006, pp. 1043-1050, at p. 1045.

${ }^{35}$ Sumon Dantiki, "Power Through Process: An Administrative Law Framework or United Nations Legislative Resolutions," Georgetown Journal of International Law, Vol. 40, Winter, 2009, pp. 655- 695, at p. 668. Also see, Philippe Kirsch, "The Role of the International Criminal Court in Enforcing International Criminal Law", American University of International Law Review, Vol. 22, 2007, pp. 539-550, at p. 541.

${ }^{36}$ Art. 24 of the UN Charter

${ }^{37} \mathrm{McD}$ ougal and Reisman, "Rhodesia and the United Nations: The Lawfulness of International Concern", American Journal of the International Law, Vol. 62, No. 1, 1968, pp. 1-20, at 9.

${ }^{38}$ Article 39 of the Rome Statute.

${ }^{39} \mathrm{Id}$ at p. 11 
of its Member States. Under Article 24, while discharging its function of maintaining international peace, the Security Council acts as an agent of the Member States of the UN. It is thus unlikely that the Council can act in a manner that is unconstrained by any norms of international law. Several restraints have thus been implied on the powers of the Security Council and these operate regardless of whether the Council acts under Chapter VII or any other part of the UN Charter. Article 24, itself sets out one limitation - the Council must act in accordance with the purposes and principles of the UN. Secondly, since the UN Charter cannot be in derogation of any norm of jus cogens, the Council that has been set up by that treaty cannot be conferred the power to act in violation of any jus cogens norm. Aside from these obvious limitations on the Council's powers, certain other restraints on its discretion have also been implied. It has been argued that the Council may not violate certain fundamental institutional principles, such as the principle of aut dedere aut judicare, and essential elements of sovereignty. The Council must also discharge its functions in good faith, and not act on the basis of ulterior motives. Since these limitations on the powers of the Security Council would apply equally to resolutions passed under Chapter VII, the validity of resolutions excluding the jurisdiction of the ICC must be analysed within this framework. ${ }^{40}$

\section{Deferral would harm the peace and security}

Using deferral as a bargaining chip with perpetrators of serious crimes harms the deterrent effect of the International Criminal Court. Deferring prosecution of Al Bashir at this point would be succumbing to the threats of criminals, not promoting international peace and security. Deferral could open the ICC to blackmail by the government of Sudan and future defendants. It could also send a message that those committing serious crimes are free to proceed without a true risk of being held accountable by the ICC. ${ }^{41}$

\section{Fear of the united states}

The United States' most serious concern regarding the ICC is the possibility that American citizens (primarily, American soldiers) could be brought before it. ${ }^{42}$ As stated previously, the ICC has

${ }^{40}$ Neha Jain, "A Separate law for Peacekeepers: The Clash Between the Security Council and the International Criminal Court," European Journal of International Law, Vol. 16, April, 2005, pp. 239-255, at p. 244.

${ }^{41}$ Jennifer Falligant, "The Prosecution of Sudanese President al Bashir: Why A Security Council Deferral Would Harm the Legitimacy of the International Criminal Court," Wisconsin International Law Journal, Vol. 27, Winter, 2010, pp. 727-755, at p. 753.

${ }^{42}$ Elizabeth C. Minogue, "Increasing the Effectiveness of the Security Council's Chapter VII Authority in the Current Situations Before the International jurisdiction over individuals who are nationals of States Parties and individuals who commit crimes in the territory of States Parties. ${ }^{43}$ So if an American allegedly committed a crime in the territory of a State Party, or in the territory of a non-State Party that accepted the jurisdiction of the ICC, then the ICC could bring that person before it. The Rome Statute provides an escape clause through the complementarity process. ${ }^{44}$ But the United States has reservations about the ICC making the determination of whether a state is able to carry out the investigation or prosecution impartially and fears that a decision of the ICC could be influenced by outside political forces instead of a thorough review of a state's judicial system.

\section{Conclusion}

The Security Council referral of the Darfur case violated the funding scheme suggested by the Rome Statute. Giving a referral power and deferral power is also putting a suspicion in the mind of the right thinking people. Why should the Security Council have power to refer a case unless and until all the members of the Security Council joins the Rome Statute. The Security Council is so powerful, apparently, that it can order a referral and even refuse to pay for it, snubbing its nose at the Rome Statute and its funding provisions. The very idea, in fact, that a criminal court should have anything to do with issues of peace and security is rather strange. Of course, one can always justify the existence of a criminal justice system with the thought that, without it, there would be mayhem. However, to allow the selection of cases to be so dependent on issues of collective security, and to be overseen by a political body concerned with it, is at odds with the fundamental goal and unique focus of all criminal courts to adjudicate the culpability of individual suspects. This dichotomy lies at the heart of international criminal justice: prosecuting individual suspects yet receiving cases when collective security demands it. ${ }^{45}$

\section{Acknowledgments}

None.

\section{Conflicts of interest}

None.

Criminal Court," Vanderbilt Law Review, Vol. 61, March, 2008, pp. 647-680, at p. 675 .

${ }^{43} \mathrm{Ibid}$

${ }^{44}$ Id at p. 676.

${ }^{45}$ George P. Fletcher and Jens David Ohlin, "The ICC-Two Courts in One," Journal of International Criminal Justice, Vol. 4, July, 2006, pp. 428-34, at p. 434. 